\title{
Perancangan dan Pembuatan Mesin Perontok Padi Berbasis Mikrokontroler ATMega32
}

\author{
Hermawansa ${ }^{1}$, Agus Susanto ${ }^{2}$, Bella Indrevaleco ${ }^{3}$ \\ Program Studi Sistem Komputer Fakultas Ilmu Komputer Universitas Dehasen Bengkulu \\ hermawansa@gmail.com
}

\begin{abstract}
The purpose of this research is to design and make paddy thresher using ATMega32 microcontroller. With this tool farmers can make the separation of rice from the stem automatically so it can reduce the risk of work and save energy. This research used ATMega32 microcontroller, photodioda sensor, 5 stem rice bar, Delphi 7 Programming language, and Bascom AVR for tool program. Test results from this paddy tool indicate the ability of sensors in detecting rice stems is good.
\end{abstract}

Keywords: Microcontroller, ATMega32, Thresher

Intisari-Tujuan penelitian ini adalah merancang dan membuat alat perontok padi menggunakan mikrokontroler ATMega32. Dengan alat ini petani dapat melakukan pemisahan buah padi dari batangnya secara otomatis sehingga dapat mengurangi resiko kerja dan menghemat tenaga. Penelitian ini menggunakan mikrokontroler ATMega32, sensor photodioda, batang padi 5 batang, bahasa Pemograman Delphi 7, dan Bascom AVR untuk program alat. Hasil pengujian dari alat perontok padi ini menunjukkan kemampuan sensor dalam mendeteksi batang padi adalah baik

Kata kunci : Mikrokontroler, ATMega32, Perontok Padi

\section{PENDAHULUAN}

Dunia teknologi informasi saat ini berkembang dengan sangat cepat, seiring perkembangan tersebut banyak muncul mesin yang dapat meningkatkan produktivitas tenaga kerja sehingga akan sangat bermanfaat untuk mendapatkan hasil kerja yang lebih efisien dan berkualitas. Saat ini mesin telah banyak digunakan oleh banyak orang baik itu dalam dunia industri besar maupun dalam industri rumah tangga dan banyak juga untuk keperluan rumah tangga.
Padi dalam kehidupan sehari-hari sangat banyak berguna baik itu untuk kebutuhan karbohidrat, makanan pokok, minuman dan masih banyak kegunaan yang lainnya. Karena banyak kegunaan kedelai dalam kehidupan sehari-hari maka memiliki nilai ekonomis yang tinggi untuk ditekuni.

Teknologi kini merambah sampai ke industri kecil atau industri rumahan, salah satunya industri kecil atau rumahan yang memiliki nilai baik dari segi ekonomis adalah yang bergerak dibidang pertaanian khusunya yang dapat membantu petani dalam melakukan pekerjaan agar menjad lebih efisien. Proses perontokan buah padi dari batangnya yang mana saat ini pengolahan masih dilakukan secara manual atau masih semi otomatis yaitu dengan memukulkan batang padi ke tempatnya sehingga akan membutuhkan tenaga dan waktu yang lama, yang mana ketika melakukan perontokan buah padi dari batangnya pekerja tidak dapat melakukan pekerjaan yang lainnya.

Dengan dibuatnya sistem ini proses perontokan padi dari batangnya dapat dilakukan secara otomatis, dengan menggunakan mikrokontroller. Maka dengan sistem ini diharapkan bisa memberikan proses perontokan buah padi dari batangnya menjadi lebih mudah, cepat, aman dan efesien dalam pemakaian tenaga. Dalam setiap pengerjaan memiliki kelebihan dan kekurangan tersendiri, misalnya proses pengerjaan dengan manual memiliki kelebihan yaitu relatif lebih murah tidak memakan biaya banyak, tetapi proses produksi akan lebih lama. Sedangkan pengerjaan secara otomatis proses produksi lebih cepat tetapi memerlukan biaya yang relatif lebih mahal. 


\section{LANDASAN TEORI}

\section{A. Padi}

Menurut Purba (2011:14) padi merupakan tanaman yang ditanam disawah yang kaya akan karbohidrat untuk tubuh dan dalam penanamannya memerlukan air yang cukup.

Menurut Maulana (2006:18) Padi merupakan salah satu tanaman budidaya terpenting dalam peradaban manusia. Dimana padi merupakan sumber atau bahan makan yang diolah menjadi menjadi beras. Padi sudah dikenal sebagai tanaman pangan sejak jaman prasejarah. Pada saat ini produksi padi dunia menempati urutan ketiga dari semua serealia setelah jagung dan gandum.

Padi termasuk dalam keluarga padi-padian atau Poaceae (Graminae). Padi termasuk terna semusim, berakar serabut, batang sangat pendek, struktur serupa batang terbentuk dari rangkaian pelepah daun yang saling menopang, daun sempurna dengan pelepah tegak, daun berbentuk lanset, warna hijau muda hingga hijau tua, berurat daun sejajar, tertutupi oleh rambut yang pendek dan jarang, bunga tersusun majemuk, tipe malai bercabang, satuan bunga disebut floret, yang terletak pada satu spikelet yang duduk pada panikula, buah tipe bulir atau kariopsis yang tidak dapat dibedakan mana buah dan bijinya, bentuk hampir bulat hingga lonjong, ukuran $3 \mathrm{~mm}$ hingga 15 $\mathrm{mm}$, tertutup oleh palea dan lemma yang dalam bahasa sehari-hari disebut sekam, struktur dominan adalah endospermium yang dimakan orang.

\section{B. Sensor}

Menurut Adi (2010: 16).Sensor adalah suatu elemen pada sistem mekatronika atau sistem pengukuran yang menerima sinyal masukan berupa parameter/besaran fisik dan mengubahnya menjadi sinyal/besaran lain yang dapat untuk diproses lebih lanjut untuk nantinya dapat ditampilkan, direkam, ataupun sebagai sinyal umpan pada sistem kendali. Kebanyakan sensor mengubah parameter fisik menjadi sinyal elektrik, misalnya tegangan atau arus, sehingga sering juga disebut sebagai tranduser, yang berarti piranti pengubah energi dari satu bentuk ke bentuk lain.

Sedangkan Menurut Sulaiman (2010:21), Sensor adalah suatu komponen elektronika yang dapat mendeteksi atau pengindera jarak jauh. Pada sistem mekatronika atau sistem pengukuran yang menerima sinyal masukan berupa parameter/besaran fisik dan mengubahnya menjadi sinyal/besaran lain yang dapat untuk diproses lebih lanjut untuk nantinya dapat ditampilkan, direkam, ataupun sebagai sinyal umpan pada sistem kendali. Kebanyakan sensor mengubah parameter fisik menjadi sinyal elektrik.

\section{Sensor Photodioda}

Menurut Adi (2010: 28) Photodioda adalah suatu jenis dioda yang resistansinya berubahubah kalau cahaya yang jatuh pada dioda berubah-ubah intensitasnya. Dalam gelap nilai tahanannya sangat besar hingga praktis tidak ada arus yang mengalir. Semakin kuat cahaya yang jatuh pada dioda maka makin kecil nilai tahanannya, sehingga arus yang mengalir semakin besar. Jika photodioda persambungan p-n bertegangan balik disinari, maka arus akan berubah secara linier dengan kenaikan fluks cahaya yang dikenakan pada persambungan tersebut.

menurut Wijanarko (2008:15) sensor Photodioda adalah suatu peralatan yang berfungsi untuk mendeteksi gejala-gejala atau sinyal-sinyal yang berasal dari perubahan suatu energi seperti energi listrik, energi fisika, energi kimia, energi biologi, energi mekanik yang bekerja berdasarkan intesitas cahaya yang diterima.

Dari uraian diatas dapat diartikan sensor photodioda adalah alat yang mampu secara langsung menangkap data kejadian fisik berdasarkan resistansinya berubah-ubah dan intensitas cahaya yang jatuh.

Photodioda terbuat dari bahan semikonduktor. Biasanya yang dipakai adalah silicon ( $\mathrm{Si}$ ) atau gallium arsenide (GaAs), dan lain-lain termasuk indium antimonide ( $\mathrm{InSb}$ ), indium arsenide (InAs), lead selenide (PbSe), dan timah sulfide 
(PBS). Bahan-bahan ini menyerap cahaya melalui karakteristik jangkauan panjang gelombang, misalnya: $250 \mathrm{~nm}$ ke 1100 untuk nm silicon, dan $800 \mathrm{~nm}$ ke 2,0 $\mu \mathrm{m}$ untuk GaAs.

\section{Mikrokontroler ATMege32}

Menurut Husanto (2007:1) mengatakan, Dunia kita bersifat analog, sehingga sistem digital yang dirancang harus dihubungkan ke sistem analog agar dapat berinteraksi dengan pengguna ataupun lingkungan. Sistem yang bertugas menghubungkan sistem analog ke sistem digital ini dinamakan interface.

Sedangkan menurut Syahrul (2014:2) Mikrokontroler adalah sebuah general-purpose device, tetapi hanya difungsikan untuk membaca data, melakukan kalkulasi terbatas pada data dan mengendalikan lingkungannya berdasarkan kalkulasi tersebut.

Dan menurut Iswanto (2008:1) Mikrokontroler merupakan chip cerdas yang menjadi tren dalam pengendalian otomatis. Dengan banyak jenis keluarga (model), kapasitas memori dan berbagai fitur, mikrokontroler menjadi pilihan dalam aplikasi procesor mini untuk pengendali skala kecil.

Mikrokontroler adalah suatu alat elektronika digital yang mempunyai masukan dan keluaran serta kendali dengan program yang bisa ditulis dan dihapus dengan cara khusus. Mikrokontroler merupakan komputer didalam chip yang digunakan untuk mengontrol peralatan elektronik, yang menekankan efisiensi dan efektifitas biaya. Secara umum bisa disebut "pengendali kecil" dimana sebuah sistem elektronik yang sebelumnya banyak memerlukan komponen-komponen pendukung seperti IC TTL dan CMOS dapat direduksi/ diperkecil dan akhirnya terpusat serta dikendalikan oleh mikrokontroler ini.

Meskipun dari sebuah kemampuan lebih rendah tetapi mikrokontroller memiliki kelebihan yang tidak bisa diperoleh pada sistem komputer yaitu, dengan kemasannya yang kecil dan kompak membuat mikrokontroller menjadi lebih fleksibel dan praktis digunakan terutama pada sistem-sistem yang relatif tidak terlalu kompleks atau tidak memerlukan bahan komputasi yang tinggi.

\section{E. Arsitektur Mikrokontroler AVR ATMega32}

Mikrokontroller AVR merupakan keluarga mikrokontroller RISC (Reduced Instruction Set Computing) keluaran Atmel. Konsep arsitektur AVR pada mulanya dibuat oleh dua orang mahasiswa di Norwegian institute of Technology ( NTH ) yaitu Alf-Egil Bogen dan Vegard Wollan. Mikrokontroler ATMega32 merupakan salah satu anggota mikrokontroller AVR 8-bit.

AVR merupakan mikrokontroller dengan arsitektur Harvard dimana antara kode program dan data disimpan dalam memori secara terpisah. Umumnya arsitektur Havard ini menyimpan kode program dalam memori permanen atau semi permanen (non Volatille) Sedangkan data disimpan dalam memori tidak permanen (Volatile). ATMega16 memiliki fitur yang cukup lengkap, mulai dari kapasitas memori program dan memori data yang cukup besar, interupsi, timer/counter, PWM, USART, TWI, analog comparator, EEPROM internal dan juga ADC internal semuanya ada dalam ATMega32.

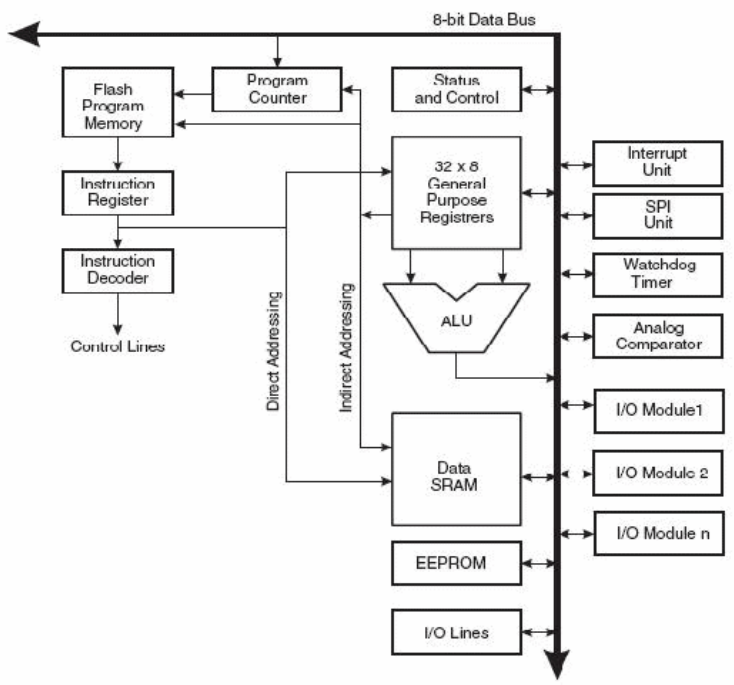

Gambar 1. Arsitektur ATMega32

Secara garis besar, mikrokontroler ATMega32 memiliki arsitektur harvard, yaitu memisahkan memori untuk kode program dan memori untuk 
data sehingga dapat memaksimalkan unjuk kerja dan pararelisme. Instruksi-instruksi dalam memori program dieksekusi dalam salah satu alur tunggal, dimana pada saat satu instruksi di kerjakan instruksi berikutnya sudah diambil dari memori program 32x 8bit register serba guna digunakan untuk mendukung operasi arithmetic Logic Unit (ALU) yang dapat dilakukan dalam 1 siklus. 6 dari register serba guna dapat digunakan sebagai 3 buah register pointer 16- bit pada mode pengalamatan tak langsung untuk mengambil data pada ruang memory data.Hampir semua instruksi AVR ini memiliki format 16-bit(word). Selain register serba guna terdapat register lain yang terpetakan dengan teknik memory mapped I/O selebar 64 byte. Beberapa register ini digunakan untuk beberapa fungsi khusus antara lain sebagai register control timer/ counter, interupsi, ADC, USART, SPI, EEPROM dan Fungsi I/O lainnya. Register- register ini menempati memori pada alamat 0x20h-0x5fh.

\section{F. Fitur ATMega32}

Berikut ini adalah fitur-fitur yang dimiliki oleh ATMega32 :

1) 130 macam instruksi, yang hampir semuanya dieksekusi dalam satu siklus clock.

2) Kecepatan mencapai 32 MIPS dengan clock 32 MHZ.

3) 512 Byte internal EEPROM.

4) $32 \times 8$-bit register serba guna.

5) 8 Kbyte Flash memory, yang memiliki fasilitas In-System Programing.

6) 512 Byte SRAM

7) Programming Lock, fasilitas untuk mengamankan kode program.

8) 4 channel output PWM.

9) 8 channel ADC 10-Bit.

10) 2 Buah timer/counter 8-bit dan 1 buah timer/counter 16-bit.

11) Serial USART.

12) Master/Slave SPI serial interface.

13) Serial TWI atau $12 \mathrm{C}$.

14) On-Chip Analog comparator.

\section{G. Konfigurasi Pin ATMega32}

Mikrokontroler ATMega32 memiliki 40 pin untuk model PDIP (Pastic Dual Inline Package) ditunjukkan pada Gambar 2.2, dan 44 pin untuk model TQFP (Plastic Gull Wing Quad Flat Package) dan PLCC (Plastic J-Lieded Chip Carrier). Nama-nama pin pada mikrokontroler ini adalah :

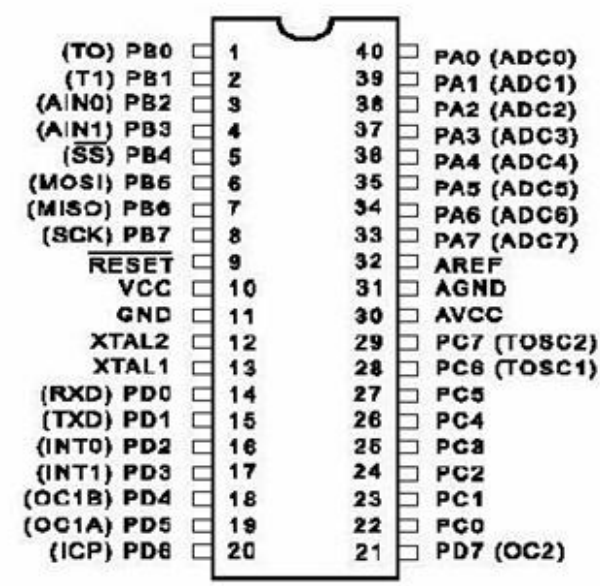

Gambar 2. Konfigurasi Pin ATMega32

1) VCC : Merupakan pin yang berfungsi sebagai pin masukan catu daya digital.

2) GND : Merupakan pin ground untuk catu daya digital.

3) Port A (PA0...PA7) : Merupakan pin I/O 8 bit dua arah (bi-directional) dan pin masukan 8 chanel ADC.

4) Port $\mathrm{B} \quad(\mathrm{PB} 0 \quad \mathrm{~PB} 7)$ : Merupakan pin I/O 8 bit dua arah (bidirectional) dengan resistor pull-up internal dan pin fungsi khusus, yaitu sebagai Timer/ Counter, komparator analog dan SPI.

5) Port C (PC0 - PC7) : Merupakan pin I/O 8bit dua arah (bi-directional)dan pin fungsi khusus, yaitu TWI (Two Wire Interface), komperator analog, input $\mathrm{ADC}$ dan Timer Osilator.

6) Port D (PD0 - PD7) : Merupakan pin I/O 8 bit dua arah (bi-directional) dan pin fungsi khusus, yaitu komparator analog, interupsi eksternal dan komunikasi serial.

7) RESET : Merupakan pin yang digunakan untuk mereset mikrokontroler.

8) XTAL1 : Merupakan input ke penguat osilator 
pembalik dan input ke internal clock.

9) XTAL2 : Merupakan out put dari penguat osilator pembalik.

10) AVCC : Merupakan pin masukan tegangan untuk ADC yang terhubung ke portA.

11) AREF : Merupakan pin tegangan referensi analog ADC.

\section{H. Editor dan Kompiler Bascom AVR}

Bascom AVR dan. Editor dan Simulator Editor Bascom jendela (File/Baru atau terbuka yang ada Bascom Program) digunakan untuk memasukkan dan memodifikasi teks program. Bascom menggunakan warna untuk menyorot teks:

1) Hijau adalah komentar: semua teks setelah '. Gunakan komentar untuk memperjelas struktur program, Anda akan terima diri sendiri ketika Anda membaca sebuah program dengan baik berkomentar setelah beberapa bulan.

2) Merah adalah untuk karakter khusus: * + -, / $/$; $<=\& \wedge \% \# @ \sim 0[] \mid @\{\} . ? !$

3) Biru (bold) adalah untuk laporan Bascom (Setiap kata yang diakui oleh Bascom sebagai memiliki arti khusus, seperti kata kunci, pernyataan, dll). Contoh: Waitms 50. Bantuan tambahan pada laporan tersedia dengan menempatkan kursor teks pada teks pernyataan dan menekan F1

4) Hitam adalah untuk variabel Bascom (lebih pada variabel).

\section{METODOLOGI PENELITIAN}

\section{A. Metode Penelitian}

Metode penelitian yang digunakan adalah metode eksperimen, dimana dalam penelitian akan membuat alat perontok padi berbasis mikrokontroller ATMega32. ADC komparator analog menghasilkan keluaran digital, Sensor Photodioda akan dijadikan input data Mikrokontroler yang siap terhubung dengan komputer ditampilkan pada PC menggunakan bahasa pemrograman Delphi 7.

\section{B. Perangkat Keras}

Perangkat keras yang digunakan dalam penelitian ini ditunjukkan pada Tabel 1.

Tabel 1. Spesifikasi Bahan dan Alat

\begin{tabular}{|l|l|l|l|}
\hline No & \multicolumn{1}{|c|}{ Alat / Bahan } & \multicolumn{1}{|c|}{ Spesifikasi } & Jumlah \\
\hline 1 & Komputer & Pentium 4, Win 7 & 1 \\
\hline 2 & Sensor & Photodioda & 1 \\
\hline 3 & Mikrokontroler & ATMega32 & 1 \\
\hline 4 & IC & IC Max232 & 1 \\
\hline 5 & Kabel & Standar & 1 \\
\hline 6 & Power Supply & 1A 5 volt & 1 \\
\hline 7 & Komp. Elektronika & Dioda, Rs 232 & 1 \\
\hline 8 & Resistor & 10k, 220 Volt & 5 \\
\hline 9 & Soket & DIP, 2x40, 2x8, 2x7 & 3 \\
\hline 10 & PCB & PCB bolong & 1 \\
\hline
\end{tabular}

\section{Perangkat Lunak}

Perangkat lunak yang digunakan meliputi sistem operasi, bahasa pemrograman dan perangkat lunak pengolah data. Sistem operasi yang digunakan adalah Microsoft Windows 7 sebagai sistem operasi. Bahasa pemrograman yang digunakan adalah Bahasa Pemrograman Basic, Bahasa Pemograman Delphi 7 untuk interface pada komputer serta Compiler editor bascom AVR.

\section{Metode Perancangan Sistem}

1) Diagram Blok Global

Diagram Blok Global dalam penelitian ini ditunjukkan pada Gambar 3.

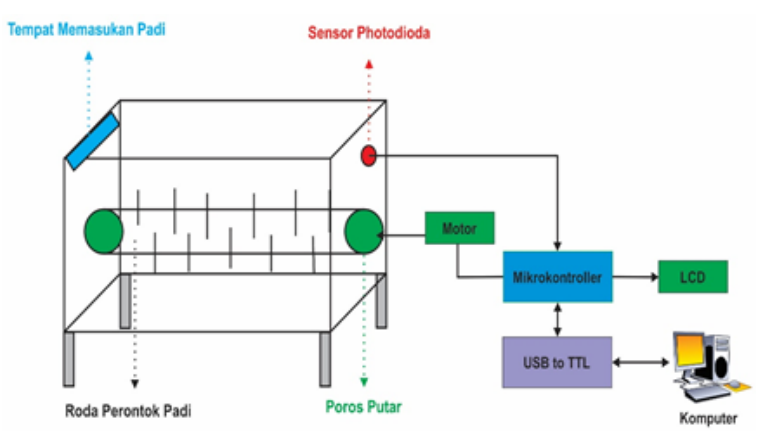

Gambar 3. Diagram Blok Global

Batang padi (yang akan dirontokan padinya) dimasukan di tempat memasukan padi. Sensor Photodioda dipasang di sejajar dengan tempat memasukan padi kedalam mesin perontok. Sensor akan mendeteksi ada tidaknya batang padi pada 
tempat memasukannya. Data hasil deteksi sensor Photodioda akan dikirim ke mikrokontroller untuk diolah. Hasil pengolahan data akan dikirim ke Aplikasi yang ada pada Komputer melalui USB 232. Disamping itu data hasil olah mikrokontroller akan dikirim ke motor atau dinamo berupa perintah kerja untuk hidup. Motor atau dinamo akan bekerja memutar mesin perontok.

\section{2) Rangkaian Alat}

Gambar 4 menunjukkan diagram rangkaian alatperontok padi yang terdiri dari sensor, rangkaian mikrokontroler ATMega32, Aplikasi PC untuk menampilkan informasi.

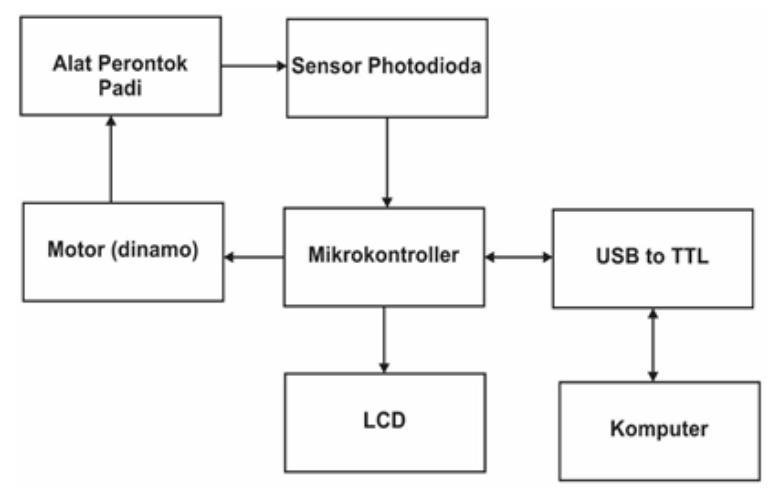

Gambar 4. Diagram Blok Rangkaian Alat

Sensor photodioda berfungsi untuk mendeteksi adanya padi pada tempat memasukan atau padi yang akan dirontokan sudah dimasukan pada tempatnya. Mikrokontroler ATMega32, berfungsi sebagai mengolah data yang masuk dari ADC dan melakukan komunikasi serial komputer.Komputer berfungsi atau dapat mengendalikan alat memalui aplikasi yang telah dirancang dan dibuat. Aplikasi PC sebagai tampilan hasil dari proses.

\section{3) Desain Rangkaian Alat}

Desain rangkaian alat dalam penelitian ini ditunjukkan pada Gambar 5. Sensor photodioda dipasang PortA pada mikrokontroler. ATMega32 mempunyai empat Port yaitu PortA, PortB, PortC dan PortD sebagai jalur bi-directional dengan pilihan internal pull-up. Aplikasi PC untuk me- nampilkan data yang sudah dideteksi. Max232 sebagai jembatan komunikasi antar mikro melalui ATMega32. Terminal penghubung konektor, Terminal 1 ke power, Terminal 2 ke ground dan terminal 3 RI IN pada max 232.

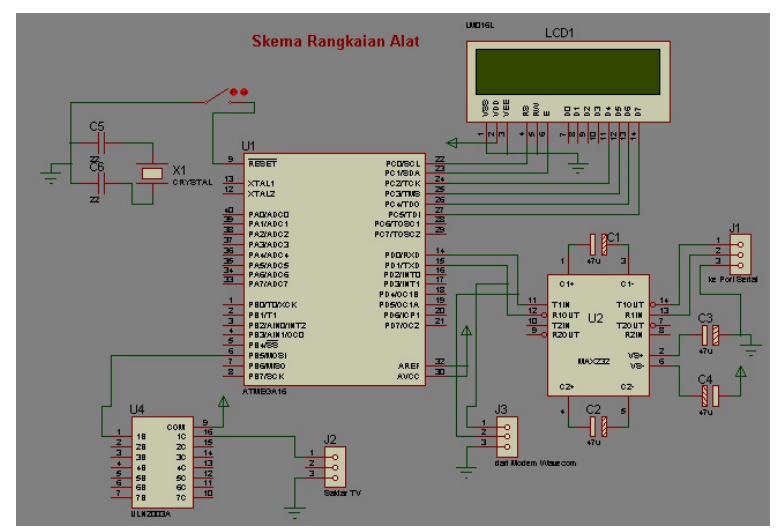

Gambar 5. Desain Rangkaian Alat

4) Rencana Aplikasi Alat Pada PC

Rencana aplikasi alat pada PC dalam penelitian ini ditunjukkan pada Gambar 6.

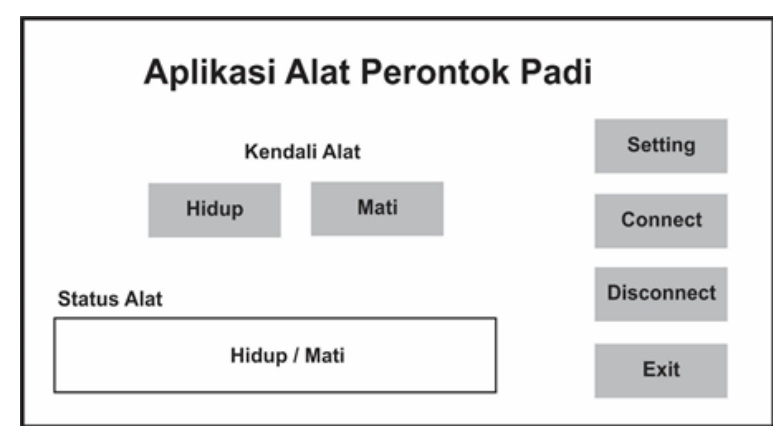

Gambar 6. Rencana Aplikasi Alat Pada PC

Aplikasi Alat Perontok Padi yaitu nama alat yang dibuat. Hidup yaitu untuk menjalankan alat secara manual. Mati yaitu untuk menghentikan alat secara manual. Setting Port yaitu untuk melakukan setting port yang digunakan untuk komunikasi antara komputer dengan rangkaian alat. Connect yaitu menghubungkan komunikasi serial antara mikrokon-troler dengan PC. Disconnect yaitu memutuskan hubungan komunikasi serial antara mikrokontroler dengan PC. Exit yaitu untuk keluar dari program.

5) Prinsip Kerja Alat

Prinsip kerja dari alat perontok padi yaitu 
ketika sistem mulai diaktifkan dengan memberikan arus listrik dari power supply maka sensor akan aktif ketika mulai memasukan batang padi ketempat memasukannya yang ada pada mesin perontok padi, dimana ketika sensor photodioda yang ada pada alat perontok padi dan mendeteksi batang padi yang akan dirontokan padinya sudah ada didalam alat maka data akan dikirim ke mikrokontroler atau sensor yang sudah aktif akan memberi data analog kerangkaian ADC kemudian ADC akan melakukan konversi atau mengubah data analog menjadi data digital pada mikrokontroler, mikrokontroler akan memberi perintah motor atau dinamo untuk bekerja memutar mesin untuk melakukan perontokan, komputer akan memonitor hasil deteksi mesin perontok padi melalui interface delphi 7.

\section{E. Langkah Kerja Penlitian}

1) Persiapan

Persiapan program dan persiapan alat dan bahan, persiapan program adalah mempersiapkan program yang akan digunakan, dalam penelitian ini dibutuhkan program yaitu PC atau laptop dengan operasi system windows 7 , menggunakan program editor bahasa basic yaitu Baskom AVR, dan program untuk membuat aplikasi yang akan digunakan untuk mengendalikan alat yaitu Program Delphi 7.

\section{2) Perancangan}

Perancangan alat dan perancangan program untuk perancangan program yang dilakukan adalah mengidentifikasi fungsi dan fasilitas apa saja yang dibutukan dalam aplikasi yang akan dibangun, dan hasilnya dituangkan dalam sebuah tampilan utama program. Sedangkan perancangan alat adalah membuat diagram rangkaian, desain alat.

\section{3) Pembuatan}

Pembuatan alat dan pembuatan Program, pembuatan program dilakukan dengan memprogram mikrokrontoler menggunakan program Baskom
AVR, sesuai dengan fungsi dan fasilitas yang telah ada pada tampilan aplikasi. Sementara pembuatan alat adalah membuat alat sesuai dengan skema rangkaian dan desain alat, pada pembuatan alat ini yang dilakukan adalah merangkai alat dan mencoba tahap demi tahap hingga selesai sesuai dengan skema rangkaian dan sesuai dengan desain rangkaian.

\section{4) Integrasi}

Integrasi alat dan program dilakukan dengan cara menghubungkan alat dengan komputer dan mencoba mengendalikan alat dengan komputer, baik memonitor masukan data dari alat, maupun memberikan perintah dari komputer dan melihat hasilnya pada alat.

\section{5) Uji coba}

Uji coba alat dan program dilakukan dengan mencoba langsung pada perangkat komputer yang dijadikan sebagai komputer uji coba, dan melihat serta menganalisis hasilnya sebagai hasil penelitian.

\section{F. Rancangan Pengujian Sistem}

Pengujian sistem dilakukan menggunakan alat perontok padi menggunakan mikrokontroller ATMega32, yaitu dengan menguji kemampuan sistem berdasarkan spesifikasi yang telah ditentukan. Pengujian sistem dilakukan terhadap kemampuan sistem berupa :

1) Ketepatan mikrokontroler dalam mengirimkan data ke komputer, serta pengujian alat yang dilakukan dengan mendemokan alat yang telah dirancang untuk merontok buah padi dari batangnya.

2) Ketepatan Sensor dalam mendeteksi.

\section{HASIL DAN PEMBAHASAN}

\section{A. Alat Perontok Padi}

Berikut adalah gambar rangkaian alat perontok padi yang telah terpasang. 


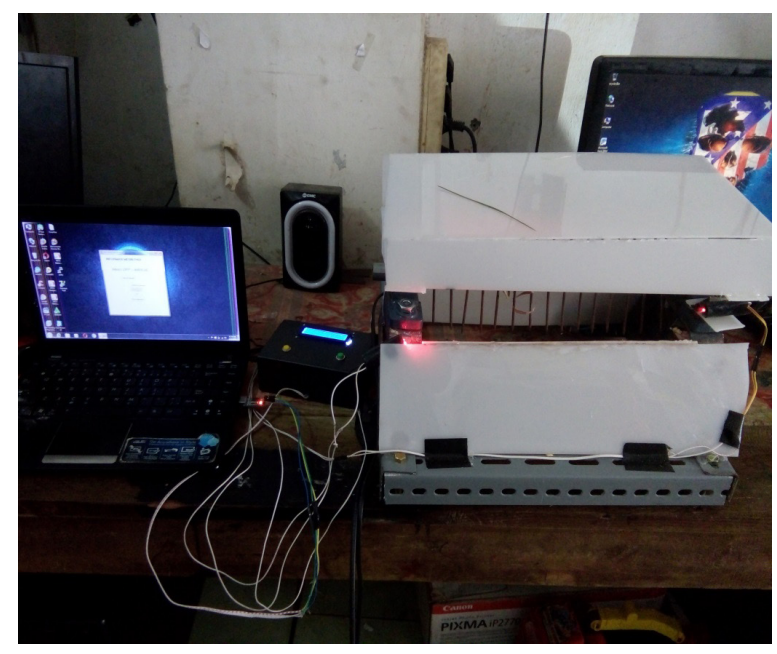

Gambar 7. Tampilan Alat Perontok Padi

\section{B. Aplikasi Alat Perontok Padi}

Tampilan aplikasi yang telah selesai dapat dilihat pada gambar berikut ini.

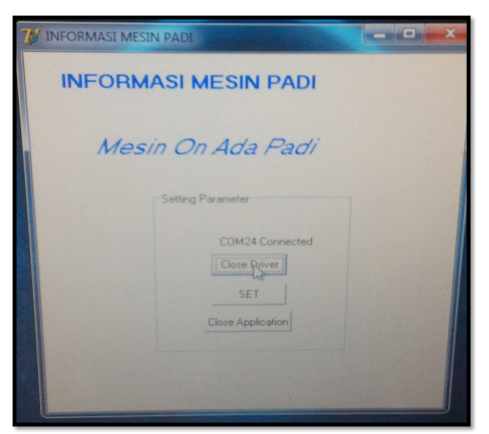

Gambar 8. Tampilan Aplikasi Pada Pada PC

\section{Prosedur Mengoperasikan Aplikasi dan Alat}

Alat perontok padi berbasis Mikrokontroller ini dapat bekerja dengan menghubungkan alat melalui komputer dan berkerja setelah semua alat terpasang dengan benar dan kondisi-kondisi. Adapun prosedur untuk mengoperasikan alat ini dapat dijelaskan seperti berikut ini :

1) Menghubungkan alat kekomputer.

2) Menghubungkan konektor USB-232 ke colokan USB komputer.

3) Menjalankan aplikasi pada komputer.

4) Setting port perintah berfungsi untuk melakukan setting port koneksi antara pc dan alat.

5) Setting port input data berfungsi untuk melakukan settingan port hubungan data antara aplikasi dan pc
6) Memasang sensor pada tempatnya dan sensor akan otomatis akan bekerja sesuai dengan fungsinya.

7) Setelah sensor mengirim data-data hasil deteksi sesuai dengan fungsinya, maka data akan di olah mikrokontroler dan setelah itu data hasilpengolahan mikrokontroler akan dikirim ke motor servo untuk bekerja sesuai dengan data hasil deteksi sensor dan kondisi-kondisi yang telah ditentukan.disamping itu data juga akan segera terkirim ke PC dan akan ditampilkan informasi-informasi sesuai dengan hasil deteksi sensor dan kondisi alat.

\section{Hasil Pengujian}

Pengujian dilakukan dengan menguji alat perontok padi di lakukan dengan cara meletakan sensor pada tempat yang telah di tentukan yang selanjut sensor akan mendeteksi adanya padi dengan fungsi dari masing-masing sensor tersebut yang selanjutnya dikirim ke mikrokontroller untuk diolah. Dimana data hasil olahan mikrokontroler tersebut disamping dikirim ke PC juga dikirim ke motor untuk bekerja melakukan hidup matinya alat sesuai dengan ketentuan yang telah diberikan seperti jika ada padi maka alat akan berjalan. Pengujian akan dilakukan dengan menggunakan alat yang telah terhubung ke komputer. Kemudian kita dapat mengatur proses jalannya alat dengan aplikasi yang ada dikomputer, untuk memulai aplikasi ini harus menghubungkan komputer dengan alat kemudian buka aplikasi yang ada pada komputer, maka kita dapat menekan tombol Open Driver untuk mensingkronisasikan alat dengan PC, Set untuk menentukan parameter-parameter yang dipakai seperti port yang digunakan dan lan sebagainya, Close Aplikasi untuk keluar dari aplikasi, dari perintah-perintah yang diberikan oleh aplikasi, kemudian oleh mikrokontroler perintah tersebut diproses sesuai fungsi tombol pada aplikasi.

Dari hasil pengujian alat perontok padi berbasis mikrokontoller berjalan sesuai dengan harapan. Hasil Pengujian seperti pada Tabel 2. 
Tabel 2. Hasil Pengujian

\begin{tabular}{|c|c|c|c|}
\hline No & Instrumen Pengujian & Hasil & Keterangan \\
\hline 1 & $\begin{array}{l}\text { Sensor Photodioda } \\
\text { Kemampuan sensor mendeteksi ketika } \\
\text { batang padi dimasukan kealat }\end{array}$ & terdeteksi & Sensor mendeteksi ketika adanya padi \\
\hline 2 & $\begin{array}{l}\text { Kemampuan Mikrokontroller } \\
\text { A. Menerima data dari sensor }\end{array}$ & Bekerja & $\begin{array}{l}\text { Mikrokontroller mampu menerima data dari } \\
\text { sensor dengan baik sehingga pada saat sensok } \\
\text { mendeteksi adanya padi maka mikrokontroler } \\
\text { akan langsung bekerja dan alat akan langsung } \\
\text { berfungsi (ON). } \\
\text { Mikrokontroler juga akan bekerja dengan } \\
\text { mengirim data ke LCD dengan tampilan ON } \\
\text { di LCD }\end{array}$ \\
\hline 3 & $\begin{array}{l}\text { Kemampuan LCD menampilkan kondisi } \\
\text { Alat (hidup/mati) }\end{array}$ & Bekerja & $\begin{array}{l}\text { Pada saat alat hidup atau mati LCD akan } \\
\text { menampilkan stasus alat dengan cara } \\
\text { menampilkan ON/OFF }\end{array}$ \\
\hline 4 & $\begin{array}{l}\text { Kemampuan motor menerima perintah } \\
\text { dari mikrokontroller }\end{array}$ & Bekerja & $\begin{array}{l}\text { Pada saat ada perintah dari mikrokontroler } \\
\text { maka motor akan lansung bergerak atau hidup }\end{array}$ \\
\hline 5 & Kemampuan Aplikasi pada komputer & bekerja & $\begin{array}{l}\text { Pada saat sensor mendeteksi adanya padi } \\
\text { dan aplikasi akan langsung merespon dengan } \\
\text { adanya tulisan ON pada aplikasi. }\end{array}$ \\
\hline
\end{tabular}

\section{KESIMPULAN}

1) Masing-masing sensor hendaknya dipasang pada tempat yang tidak akan menghambat fungsi dari pada sensor tersebut.

2) Bahasa Pemograman Aplikasi disini menggunakan Delphi 7 karena kecepatan untuk komunikasi antara aplikasi dan mikrokontroller. Seperti diketahui data yang dikirim dan diterima membutuhkan proses yang cepat sehingga dapat menampilkan data yang sama dengan hasil deteksi sensor.

3) Hasil penelitian menunjukan bahwa hasil deteksi sensor akan mempengaruhi motor servo untuk bekerja atau tidak.

4) Mikrokontroler sangat berguna untuk mengolah data dari hasil deteksi sensor untuk melakukan perintah pada motor servo dan kirim ke PC untuk ditampilkan.

\section{DAFTAR PUSTAKA}

Abdul Khadir. 2008. Dasar Pemrogram Delphi7. PT. Elek Media Koputindo. Jakarta.

Adi Nugroho. 2010. Rekayasa Perangkat Lunak Berbasis Objek dengan Metode USDP. Andi. Yogyakarta
Ahmad Alwi. 2007. Kamus Besar Bahasa Indonesia (Bidang Kimia) Edisi Revisi. Graha Ilmu. Yogyakarta

Awal Maulana, 2009. Irigasi Yang Tepat Untuk Bertanam Padi. IPB. Bandung

Harimurti Kridalaksana. 2008. Kamus Liguistik (Edisi Keempat). PT. Gramedia Pustaka Utama. Jakarta

Iswanto, 2008. Design dan Implementasi Sistem Embedded Mikrokontroller ATMega8535 Dengan Bahasa Basic. Gava Media. Yogyakarta Jhon Hardy Purba, 2011. Cara Memanfaatkan Aliran Air Untuk Bercocok Tanam Padi di Persawahan. Departemen Pertanian RI. Jakarta

Mulyono, 2008. Komputer Dasar Bagi Tahap Pemula. Jakarta, Pt. Elek Media Koputindo.

Rudi Wijanarko. 2008. Komponen Elektronika Untuk Otomatisasi. Graha Ilmu. Yogyakarta.

Sulaiman Abdullah. 2010. Panduan Singkat Perakitan Robot Bagi Pemula. Andi. Yogyakarta

Susilo Deddy, 2010. Pengenalan Mekatronika Dasar. Yogyakarta. Graha Ilmu

Syahrul, 2014. Pemograman Mikrokontroler AVR Bahasa Assembly dan C. Infomatika. Bandung Thomas \& Husanto, 2008. Kupas Tuntas Mikrokontroller PIC16F84. Yogyakarta. ANDI 